\title{
Socio Cultural Phenomenon and Citizenship Rights of Indigenous Communities in Remote Island Buru
}

\author{
F. Sialana \\ Post Graduate Studies of Civic Education \\ Universitas Pendidikan Indonesia \\ Bandung, Indonesia
}

\begin{abstract}
This study aims to determine the various phenomena and problems that exist in remote indigenous communities or people bupolo Buru island. This research uses the ethnographic method with a qualitative approach. The results showed that the Remote Indigenous Communities has not fully accept their rights as Indonesian citizens deserve. Those rights include social rights, economic rights, the right to education, health, etc. From the aspect of culture is still a lot of traditions, customs and practices that hamper the community in accepting various development programs and social services. The problems of the government itself associated with a minimal budget in the implementation of development programs and cross-sectoral coordination is not maximized. The result is expected to provide benefits to society bupolo, government and stakeholders in the district of Buru.
\end{abstract}

Keywords: Socio Cultural Phenomenon, Rights of Citizenship, Remote Indigenous Communities, Bupolo

\section{INTRODUCTION}

As a democratic country and the state of law, Indonesia underpin life on the rules that protect and regulate the rights and obligations of citizens. In 1945 described the rights and obligations of citizens of Indonesia are not differentiated on the basis of male and female. Men and women have the same rights and obligations in his status as a citizen of Indonesia. In chapters 27 to 31, Amendment of the 1945 Constitution clearly guarantees the rights and obligations of citizens both men and women in all areas of life, among others, the fields of law, politics, economics, education and others.

The implication is often the rights that should be accepted by the citizens it is not met. Instead the government has to provide the needs of the community but with reason is contrary to the culture and customs often denied these rights. One of the ethnic groups is still adhere to customs and culture are Bupolo. They are an isolated indigenous communities living in the island of Buru. They live in the mountains, slopes, remote villages and some are already living in the lowlands. Despite living in the lowlands but still flocking in their own communities. In the terminology of the mention of the Bupolo Buru intended for indigenous people or those who claim to be genuine and the owner of the island of Buru (Max Pattinama, 2013).

Remote indigenous communities as part of Indonesian society is the bottom layer in the structure of society. Geographically residing in isolated areas and difficult to reach.
Social institutions that developed in remote indigenous communities generally rely on kinship where their daily activities are still based on blood ties and ties the knot (Social Department 2003) . Furthermore, the Ministry of Social Affairs gives the definition of Remote Indigenous Communities that the Remote Indigenous Communities is a socio-cultural group that is local and dispersed and less or not involved in the network and the services both social, economic and political (Decree No. III / 1999).

As citizens, Remote Indigenous Communities have the right to live in prosperity, the right to basic social services, the right of participation in the development and protection of the rights of a variety of conditions that interfere, whether social, cultural, economic, legal and political. Various rights owned Remote Indigenous Communities that need attention and fair treatment from the government, as the behavior of the state in fulfilling the rights of citizens in general. The nation's attention to the Remote Indigenous Communities is an implementation of the state's obligation in meeting the welfare of all citizens.

Since the change in the nomenclature of the tribal (1971) and isolated communities (1980) and now remote indigenous communities (1999) Remote Indigenous Community population has been scattered in 30 provinces that inhabit almost all parts of Indonesia. Based on the results of the data update Remote Indigenous Communities nationally there're 229,479 household was in 2658 locations. They are scattered in 246 districts, 852 districts, 2037 villages and 2650 locations. They inhabit a variety of habitats, such as upland, lowland/ swamp, inland/mountain and coastal/marine ( Ujangth, 2009).

The quantitative data shows that the total population and the spread of Remote Indigenous Communities in Indonesia is relatively small when compared with the population of Indonesia, but the problem condition has great resonance because it is not apart on the issue of poverty in general.

Soulisa (2012) in his research in South Buru Bupolo explains that women are still not yet fulfilled their rights as citizens of Indonesia. A lot of discrimination experienced by women Bupolo. Further explained that the discrimination felt by women Bupolo associated with some rights that are not being met as befits a man Bupolo. Women's rights Bupolo unmet among others the right to determine the spouse (husband), the right of expression, the right to enjoy proper education, the rights of government (village heads, heads of customs, agency customs, etc.), as well as rights in religion (ministry in the 
Church). Similarly Sialana (2006) that discrimination against women Buru rights include the right to pursue formal education and foster a culture mating (early marriage).

Of course what is experienced by women Bupolo is contrary to the 1945 Constitution and other legislation governing the rights of Indonesian citizens, regardless of sex. The articles of the 1945 Constitution as well as various other regulations explicitly regulate the rights of Indonesian citizens and obligations as citizens of Indonesia. 1945 express or implied explained that the state protects, guarantees and regulates the rights of Indonesian citizens in various aspects of life.

Formulation of the problem in this study were 1) How sociocultural conditions of remote indigenous communities of the island of Buru 2) How Remote indigenous communities Buru problems related to the rights of citizenship 3) How the government's efforts in meeting Buru citizenship rights of Indigenous Communities Remote island of Buru.

This research was conducted in order to meet the final project as a doctoral student Indonesian Education University (dissertation ). This study is unique and advantages compared to other studies. This is because the culture of the indigenous people Buru very unique and different from other indigenous peoples in Indonesia. besides it's still a bit of researchers who conduct research on Remote Indigenous Communities in Buru . Expected results of this study can contribute to the Buru regency government in raising the living standard of the Bupolo and fulfill their rights as citizens of Indonesia.

\section{RESEARCH METHODS}

This study uses qualitative ethnography approach . Reason methods and research approaches been considered problem is a cultural problem related to their rights as citizens of Indonesia.

Spradley (1997:3) explains that ethnography is to describe a work culture. The main objective of this activity is to understand a view of life from the viewpoint of indigenous people. As noted by Malinowsky (Spradley, 1997: 3) the purpose of ethnography is to understand the viewpoint of the indigenous people, to do with life, to get a view of his world. Therefore, ethnographic research activity involves learning about the world of people who have learned to see, hear, speak, think and act in different ways. Not only learn the community, more than that ethnography is to learn from the community.

Design study conducted by researchers: a) Determine the theory in accordance with the state of the field, b). Determining the instrument of accession of research and data collection techniques , c) Plan for data analysis , d) The plan reaches the level of truth research, e) To prepare the issues to be investigated.

Research subjects are traditional leaders, community leaders, local government. Buru include officials in the department of education, health services, social services, Parliament, the Regent and led Organizations.

In qualitative research, data collection is done in a natural setting (natural conditions), the primary data source, and data collection techniques more on participation observation, in depth intervieu and documentation.
Data analysis techniques used in research on Remote Indigenous communities Buru is qualitative data analysis, following the concept given by Miles and Huberman. Miles and Huberman (1984) suggest that activity in qualitative data analysis performed interactively and continues over time until complete, so the data is already saturated. Activity in the analysis of the data, that is data reduction, data display, and conclusion drawing / verivication.

\section{RESULT AND DISCUSSION}

\section{A. Socio Cultural Conditions Remote Indigenous Communities Buru Island}

Buru indigenous people or people Bupolo is one of hundreds Remote Indigenous Communities in Indonesia . Buru for society in general and migrant communities they called the mountain, the balakang, or alifuru. Social life is still very simple. Still very strong on kinship based clan, clan or soa ( genealogical ). Very uphold the customs and habits of life handed down from his ancestors until now. They still believe in myths, taboos - taboos and traditions are laden with restrictions as controller and regulator of social norms and customary norms upheld by the local community.

In terms of confidence Bupolo people believe in "Opu Lastala" which is regarded as their God. This is a genuine belief that the local community has not embraced Islam and Christianity . Most of the people who live in the plains Bupolo Low had converted to Islam and Christianity. Uniquely within a family there who embrace "traditional religion", Islam and Christianity .

Generally people bupolo live simply by exploiting natural potential possessed. Their livelihoods, among others, gardening, farming, gathering and hunting. In utilizing the even nature always maintain its sustainability. Never encountered illegal logging or burning of forests illegally. They are very appreciative of nature because of the local belief that God's nature is entrusted should always be preserved.

\section{B. Problems Related to Remote Indigenous Communities Buru Rights of Citizenship}

TH Marshall in his book Citizenship and Social Class (1950 ) stated citizenship as "a status bestowed on Reviews those who are full members of a community (including civil, political , social rights)". Based on the statement he made two conceptualization of citizenship. First, citizenship is a status that is attributed / given / awarded by a political community in this country to people who are members. Secondly, it is the status of a basic set of rights which include civil, political and social. Civil rights with regard to the rule of law and freedom of speech; political rights associated with formal legal political process especially right to be elected or elect; and contains the right to social security and welfare were feasible as fellow citizens. Thus citizenship implies a formal legal equality. The three elements that create citizenship.

Referring Marshall of theories about the rights of citizenship , then Sri Wuryani and Syaifullah (2006) classify Citizenship Rights in the distribution of rights as follows:

a. Civil and political Rights, which includes: 1) Right to life, 2) Right to liberty and security of person, 3)Right 
to equality before the courts and tribunals, 4) Right to freedom of thought, conscience and religion, 5) Right to hold opinions without interference 6) Right to peace full assembly 7) Right to freedom of association.

b. Economic, social, and cultural, which includes: 1) Right to work, 2) Right to form trade unions, 3) Right to social security, 4) Right to an adequate standard of living himself and his family, including adequate food, clothing, and housing, 5) Right to education.

The results showed that the culture of the Bupolo (Remote Indigenous Communities) in some aspects there is still gender discrimination. This can be seen in one of the traditional marriage "kaweng piara" or "kaweng sasi" (aged marriage). Kaweng Piara a legal marriage system in indigenous communities Buru where girls (future wife) "mated" customary with men (husbands) selection of parents since the girl was still in his mother's womb. In the process of making a proposal of this man as a potential husband to provide for all the needs of women (future wife) until the time comes ready to have intercourse and included in the families of men as wives. (Fatimah 2006, Soulissa 2011). As a result of this suspension mating males (husbands) issued a marriage treasure very much. The impact of this marriage is a man in society Bupolo may have many wives as long as he was able to support his wife and issued a marriage treasure very much.

What applies in the mating system of this Bupolo society customary law is legal but legally and formally contrary to the 1945 Act . In 1945 the results of the amendment of Article 28B paragraph (1) states that " everyone has the right to form a family and continue the descent through legal marriage". While paragraph (2) states that "every child has the right to live, grow and develop and has the right to protection from violence and discrimination". This means that very child / person has the right to form a family and continue the descent on its own volition without coercion much less violent than others. What is written in 1945 is also confirmed in Law No. 11974 article 7 ( seven) that "marriage is only permitted if the man has reached the age of 19 ( nineteen ) and the woman has reached the age of 16 years". Article 6, paragraph (1) which reads "Marriage shall be based upon the consent of both bride".

One of the citizenship rights that must be owned by the citizens is the right to education, especially basic education of 9 years. For it is based on the 1945 amendments, the government allocates 20 percent of the state budget and the budget for the education sector. Bupolo people, especially in the highlands until now have not enjoyed a schooling education they deserve. Bupolo are still many people who are illiterate, especially in mountainous areas (plateau). Access to education is still lacking , shortage of human resources and teachers lead the public is very low quality. While in the lowlands and coastal still minimal school facilities, especially electric power and a variety of books and tools that may be supporting the activities of students and teachers.

Many of the problems related to the poor quality of education on Remote Indigenous Communities in Buru. The first, Bupolo people who live in the highlands still live in groups in a village or region. Usually in one location stay between 4 to 10 households. Spread of residence location was quite far from one region to another. As for building schools in areas that can not be occupied by only a few households. This is why the indigenous people who live in groups is difficult to obtain education schooling because of the location where he lives very far from the location of the school. Secondly, the habit of parents bring their children to the whole farm / garden for weeks or even months. This causes their children can not attend school education as well. Third, indigenous peoples still do not understand the importance of formal education in improving the quality of life and the future of their children, it is becoming the main cause of the parents are not interested in sending their children. Fourth, there is no teacher housing in the area of Remote Indigenous Communities so that teachers are assigned to schools on Remote Indigenous Communities highly experienced problems in performing their duties. Long distance, access to school passing through the woods, hills, mountains swamp lead teachers often truant and did not do their job properly. Fifth, learning facilities and school buildings are inadequate cause not passionate teaching and learning activities that adversely affects the quality of the learners. Sixth, the children are involved in "kaweng piara" as described previously formal education. This is because in a certain age they have the status of a wife or husband.

From the aspect of health, indigenous people still rely on traditional medicine. Medical treatment is still less attractive to the local community. Parturition still rely on the services the village shaman. Public health centers and Public health sub centers only in the sub-district towns and some villages. Not all villages have a Public health center. While the health services in the form of intense immunization is done in the form of health workers visit the villages and hamlets of Remote Indigenous Communities. But in these efforts are often facing obstacles like old people who are still reluctant and scared her an injection. Lack of knowledge about medical health remained a major constraint in the provision of health services in remote indigenous communities. Ironically, there is one custom that is still valid to this day the indigenous child or children "Koit" where not just anyone can touch. In one case, for example, when handling pregnant women can not be carried out normally, the medical procedure that must be done is cesarean section. But in fact an attempt was rejected by the patient's family by reason of the child to be born is his mother's son "koit" which should not be touched. Due to the refusal of the Remote Indigenous Communities patients died.

Another issue is the Remote Indigenous Communities Buru electric lighting. This problem is not only felt by the public Bupolo at High plains, but in the plains Low even in the district town though. Some city districts in Buru regency until now felt only illumination at night. Crocodile Water District already 40 years into districts until now the power is on only at night. While in some villages, which are located in the city district and even no electric lighting at all.

From the aspect of transportation and the road is still far from eligibility. There are still many rocky roads, potholes, unpaved, dusty, causing access to the location remote Indigenous communities have problems. Generally the roads are paved main roads or highways. While the road to and from the location of the Remote Indigenous Communities is still worth taking. In the highlands for example journey through the hills, forests, lakes, 
swamps, and rivers. Buru itself up to now the main vehicle is a motorcycle taxi citizens. Namlea in the city which is the capital of Buru no public transportation kind of public transportation. Public transportation is provided only for the Distance between districts. The Government argued that the construction of infra structure constraints in Buru is the lack of budget to finance the construction, but gradually the government has had a plan to make changes and planning gradually in pembagunan in various sectors.

\section{Buru Regency Government's Efforts in Meeting the Citizenship Rights of Indigenous Communities Remote Island Of Buru}

To overcome the problems of education and health, particularly the lack of teachers and medical workers, then some of the policies and programs of Buru district government has done in the form of scholarships to indigenous peoples for formal education at some universities in Java. Upon his return to the area is expected to serve their own communities so that health and educational problems can be resolved.

Gradually the government will build and renovate schools and livable housing for people and teachers at the location of Remote Indigenous Communities. Likewise with medical workers will be placed in Public health centers and public health sub center available on Remote Indigenous Communities.

Gradually the government is carrying out the construction of infrastructure of the widening and paving of the main streets in Buru, gradually implementing rural electrification, as well as creating programs Remote Indigenous Communities empowerment.

\section{REFERENCES}

[1] Max MJ. Pattinama. (2013, 26 Maret). Orang Bupolo di Waeken. Bupolo [Online]. avaliable: http://maxmjpattinama.unpatti.org/2013/03/ orangbupolo-diwaeken/ [15 September 2015].

[2] Departemen Sosial RI. Pola pembangunan Kesejahteraan Sosial. Jakarta: Direktorat Jenderal Pemberdayaan Sosial. 2003.

[3] Keputusan Presiden RI Nomor III Tahun 1999 Tentang Pemberdayaan Sosial Komunitas Adat Terpencil.

[4] Kementerian BPN/Bappenas. Masyarakat Adat di Indonesia: Menuju Perlindungan Sosial yang Inklusif. Direktorat Perlindungan dan Kesejahteraan Masyarakat. 2003.

[5] Ujangth.( 2009, 14 Desember). Komunitas Adat Terpencil Dalam Data. Kementerian Sosial Republik Indonesia [Online]. Tersedia: http://www.kemsos.go.id/modules.php?name=News\&file $=$ article \&sid=1 377 [12 September 2015].

[6] Jalvin Soulisa. Anavina Fuka Bupolo Suatu tinjauan kritis dari Perspektif Kesetaraan Jender Terhadap Peran dan Kedudukan Perempuan dalam Gereja dan Masyarakat di Buru Selatan. Salatiga: Universitas Kristen Satyawacana. Tesis. 2012.

[7] Fatimah Sialana. Peranan Faktor Budaya Dalam Pengembangan Pendidikan Di Kalangan Penduduk Asli Pulau Buru. Bandung: Universitas pendidikan Indonesia. Tesis 2006.

[8] James Spradley. Metode Etnografi. Jokja: Tiara Wacana. 1997

[9] Miles Mathew B; Huberman Michael A. Qualitative Data Analysis a Sourcebook of New Methode. London: Sage Publications. 1984

[10] TH. Marshall. Citizenship and Sosial Class. London: Cambridge at the University Press. 1950.

[11] Wuryani, S. dan Syaifullah. Ilmu Kewarganegaraan (Civics). Bandung: Laboratorium UPI. 2008.

[12] UUD 1945 Hasil Amandemen dan Penjelasannya.

[13] Undang-Undang Republik Indonesia Nomor 1 Tahun 1974 Tentang Perkawinan dan Komplikasi Hukum Islam. Bandung: Graha Media Press 